\title{
Adoption of International Financial Reporting Standards Has Enhanced Chinese Company Transparency
}

\author{
Jing Lin, João Neiva de Figueiredo, A. J. Stagliano \\ Saint Joseph's University, Philadelphia, PA, USA
}

\begin{abstract}
The research reported here shows that China's recent adoption of Accounting Standards for Business Enterprises (ASBE) has increased the quality of Chinese financial reporting. With China's decade of World Trade Organization (WTO) membership marked by dazzling economic growth, it is useful to reflect on how financial reporting itself can assist in the country's future progress. Critical to the success of ensuring strength for this burgeoning economy is attraction of foreign investment capital. As China's internal consumption grows, cross-border economic linkages will increase and require new investment inflows for further infrastructural and macroeconomic development. Only a reliable, trusted, and transparent financial reporting framework can ensure credibility in the world market for scarce capital resources. Evidence from this study covering six years for more than 1,200 publicly traded Chinese firms points to enhanced quality of financial reporting. This is an important empirical finding that demonstrates the benefits of adopting global financial reporting standards. China, which still relies heavily on governmental planning, has recognized the need for more transparency in financial market operations. Superior company reporting and enhanced quality of reported earnings numbers significantly contribute to greater domestic and foreign investor confidence in Chinese institutions.
\end{abstract}

Keywords: accounting standards, Accounting Standards for Business Enterprises (ASBE), earnings quality, International Financial Reporting Standards (IFRS), income smoothing

\section{Introduction}

This paper reports on an assessment of the quality of the financial reporting made by Chinese companies. Motivation for the empirical examination comes from the recent mandatory implementation of a new set of Chinese accounting guidelines, the Accounting Standards for Business Enterprises (ASBE). Although ASBE are indigenous domestic standards, they are considered to be substantially equivalent to the worldwide benchmark International Financial Reporting Standards (IFRS) that have been developed by the International Accounting Standards Board (IASB). As the second largest economy in the world, China's recent move to bring its national accounting standards closer in line with IFRS is indicative of a continuous effort to further convergence with the global financial reporting framework.

ASBE was issued in February 2006 by China's Ministry of Finance (MOF); it was set for implementation

Jing Lin, Ph.D., Associate Professor of Accounting, Erivan K. Haub School of Business, Saint Joseph's University.

João Neiva de Figueiredo, Ph.D., Associate Professor of Management, Erivan K. Haub School of Business, Saint Joseph's University.

A. J. Stagliano, Ph.D., Professor of Accounting, Erivan K. Haub School of Business, Saint Joseph's University.

Correspondence concerning this article should be addressed to A. J. Stagliano, 5600 City Avenue, Philadelphia, PA, USA 19131-1395. E-mail: astaglia@ sju.edu. 
by all Chinese publicly traded companies beginning on January 1, 2007. Over the past two decades, the MOF now has prescribed a series of four different accounting regulations in 1992, 1998, 2001, and 2006 (Peng \& van der Laan Smith, 2010). Each of these pronouncements is emblematic of significant progress toward convergence with international standards. By promulgating ASBE, the MOF declared that China was entering a new era of globalization in its financial reporting practices (Ding \& Su, 2008).

The goal of the IASB is to develop a single set of high quality accounting standards for worldwide application in financial reporting. Given the increasingly important role that China plays in the world market, this research explores whether the adoption of ASBE, an IFRS-based standard, has resulted in an improvement in financial reporting by Chinese companies. The main focus in this paper is on the quality of earnings reported by publicly traded firms.

To measure earnings quality, three indicators are adopted: (1) smoothing of earnings; (2) earnings being managed toward a positive target amount; and (3) timeliness of loss recognition. The data are taken from companies reported in the Chinese Securities Market and Accounting Research (CSMAR) files for the period from 2004 to 2009. A total of 1,220 unique firms that have financial data across all seven years (including 2003 as the base year) are identified for the final analysis. By design, an equal number of firm-year observations $(3,660)$ were created in the pre- and post-ASBE study periods of 2004 to 2006 and 2007 to 2009, respectively.

The empirical results indicate more fluctuations in net income subsequent to the time when ASBE was implemented. The variability of net income relative to the variability of cash flows also is higher in the post-ASBE period; this outcome suggests reduced earnings smoothing activities following the adoption of IFRS-based accounting standards. Companies seem more likely to manage earnings toward a positive target in the post-adoption period. At the same time, firms tend to engage in more timely loss recognition after ASBE became effective. Taken together, the findings suggest an increase in earnings quality associated with the adoption of IFRS-convergent accounting standards in China.

In the next section, the relevant literature is viewed. The testable hypotheses and research design are given in the third section. The sample and results are described in the fourth section. The fifth section concludes the paper with an analysis of the results along with a discussion of their usefulness in the context of China's emergence as a world economic power.

\section{Background Literature}

The primary objective espoused by the IASB is establishment of a single robust set of high quality global accounting and reporting standards. To that end, this body has worked over the years with many national standard-setting groups to bring about convergence. Currently, more than 100 countries either permit or require IFRS for public companies. Additional nations are expected to transition to IFRS over the next few years. Since the idea of a uniform framework of accounting and reported emerged more than 40 years ago, the concept has generated a great deal of academic (and financial-press) literature.

One particularly interesting stream of research has centered on the initial impact of IFRS adoption. Daske, Hail, Leuz, and Verdi (2008) examined the economic consequences of mandatory IFRS reporting in 26 countries. They analyzed the effects on financial-instrument market liquidity, firms' cost of capital, and Tobin's $q$, documenting an increase in market liquidity around the time of the IFRS introduction, a reduction in firms' cost of capital, and an increase in equity valuations. They discovered, inter alia, that the capital-market benefits occur only in countries where firms have incentives to be transparent and when legal enforcement is 
strong - thereby underscoring the importance of understanding firms' managers' reporting incentives and countries' enforcement regimes in assessing the quality aspect of financial reporting.

Focusing on accounting quality, Barth, Landsman, and Lang (2008) studied the adoption of International Accounting Standards (IAS), the international principles framework that preceded IFRS, in 21 countries. They measured accounting quality on three dimensions: earnings management, loss recognition, and value relevance of accounting amounts. They found that firms applying IAS generally showed less earnings management, more timely loss recognition, and higher value relevance of accounting amounts than do like firms that adhered to different domestic standards alone. They suggested that an improvement in accounting quality was documented in the post-adoption period.

Chen, Tang, Jiang, and Lin (2010) investigated the 2005 mandatory adoption of IFRS by 15 member states in the European Union (EU). Comparing the accounting quality of publicly listed companies before and after full adoption of IFRS, the authors found higher post-adoption accounting quality for many indicators-less earnings management toward a target, reduced absolute magnitude of discretionary accruals, and higher accruals quality. However, there also was evidence that firms engaged in more income smoothing activities and recognized large losses in a less timely manner after the transition to IFRS. Overall, they attributed the quality improvement to adoption of IFRS rather than potential changes in managerial incentives, institutional features of capital markets, or the general business environment. In another study that examined the value relevance of IFRS adoption in the EU, Armstrong, Barth, Jagolinzer, and Riedl (2010) identified 16 events leading to the formal adoption and document a number of positive market reactions to these. Their results suggest that investors expect information quality benefits from IFRS adoption.

Researchers also have examined IFRS adoption impacts in various individual country settings. For example, Jeanjean and Stolowy (2008) concentrated their analysis on three IFRS first-time adopter countries: Australia, France, and the United Kingdom (UK). They found that the pervasiveness of earnings management did not decline after the introduction of IFRS. In fact, they observed an increase in earnings management among French companies. Their conclusion was that the "switch" to IFRS did not convincingly result in an overall improvement in terms of earnings quality. Horton and Serafeim (2010) focused their study on the UK in an attempt to determine whether disclosure of IFRS reconciliation adjustments for previously published UK GAAP (Generally Accepted Accounting Principles) statements had information content. Looking at six adjustment areas most directly affected by the IFRS requirements, they concluded that these reconciliation adjustments had measurable incremental value relevance when compared to the UK GAAP numbers.

Several excellent studies have been conducted on IAS/IFRS adoption in Germany. For instance, Hung and Subramanyam (2007) investigated the financial statement impacts of changing to IAS for the years from 1998 to 2002. Although they uncovered no evidence that book value and income were more value relevant under IAS than under German GAAP (HGB), IAS income exhibited greater conditional conservatism than the HGB-reported income did; this outcome was consistent with the fair-value orientation of IAS versus the typical income-smoothing orientation of HGB. In another study of German firms (years from 2002 to 2006), Paananen and Lin (2009) concluded that accounting quality did not improve, but actually declined over the period studied.

Empirical studies conducted to have date focused almost exclusively on companies in developed countries. These have produced mixed results on the question of changes in reporting quality (C. Liu, Yao, Hu, \& L. Liu 2011). As additional developing countries endorse IFRS, interest in the effect on companies in these locations 
has grown. Ball, Robin, and $\mathrm{Wu}$ (2003) examined the quality of financial reporting of four common-law countries in East Asia: Hong Kong, Malaysia, Singapore, and Thailand. Interestingly, their analysis showed that firms' earnings did not exhibit higher quality than that evidenced in code-law countries. Their findings underscore the importance of examining managers' incentives at the same time that questions about accounting standards application are studied.

Turning to China, the subject of the new research described here, an early study by Echer and Healy (2000) compared the usefulness of statements prepared under IAS with those that followed Chinese domestic standards for the period 1993 to1997. No evidence was found that information was more useful when prepared under IAS. According to the authors, this outcome can be attributed to an absence of effective controls and financial infrastructure in China. Chen, Sun, and Wang (2002) focused on a major 1998 convergence effort by the Chinese government, issuance of "Accounting Regulation for Listed Companies" that sought to harmonize Chinese GAAP with IAS. Their results suggest that the gap between Chinese-standards and IAS-measured earnings continued to exist after the new regulations were implemented. The study's authors attribute this lack of improvement to inadequate supporting infrastructure, manifested principally by excessive earnings management and low quality auditing.

More recently, certain studies have examined the quality of financial reporting more closely than the earlier papers cited above. Zhou, Xiong, and Ganguli (2009) investigated whether Chinese firms that adopted IAS had higher earnings quality by comparing voluntary IAS adopters and non-adopters from 1994 to 2000. They discovered that adopting firms were less likely to smooth earnings, that their tolerance for reporting losses was not lower than non-IAS adopters, and that their recognition of losses was not timelier.

Similar in some ways to the study reported on below, Liu et al. (2011) examined the impact of ASBE on Chinese companies for the period from 2005 to 2008. They provide limited evidence of reduced earnings management and higher value relevance of accounting data for 2007 and 2008, the post-ASBE years, suggesting an overall increase of accounting quality. This study encompasses a significantly larger company sample, makes use of a different database (CSMAR), includes more industries, has a longer testing window, and takes into account both a company's share type (A or B) and its listing exchange. In several ways, this new study is complementary to and a natural extension of Lin, Neiva de Figueiredo, and Stagliano (2012), as it broadens the scope of that study, tests additional hypotheses, and provides further confirmatory evidence for several of the previously offered findings.

The significant amount and breadth of literature described above demonstrate the high level of interest regarding IFRS adoption around the world. This new study contributes to the growing body of literature by focusing on one important economy as it takes significant steps toward full convergence with global financial reporting guidelines.

\section{Hypotheses and Research Design}

With respect to the matter of accounting quality, the mixed findings - alluded to earlier - resulting from studying different countries over various time periods, suggest that no directional prediction be made in the statement of hypotheses. On the one hand, ASBE made fundamental changes to the previously applied Chinese accounting standards. Thus, it is possible to expect improvement in earnings quality to result from implementation. On the other hand, though, China is very different from many of those countries studied in terms of both historical development and economic philosophy. The lack of effective controls and enforcement 
mechanisms easily can lead to little or no alteration in managers' reporting behavior. Therefore, it is prudent to state a simplified general hypothesis that mandatory adoption of ASBE impacted Chinese firms' earnings quality without suggesting that either improvement occurred or quality diminished.

Three commonly used measures were adopted to proxy for earnings quality: earnings smoothing, managing earnings toward a positive target, and the likelihood of recognizing losses in a timely manner.

The three hypotheses that will be tested are stated as follows:

$\mathrm{H}_{1}$ : Mandatory adoption of ASBE affected Chinese firms' earnings smoothing.

$\mathrm{H}_{2}$ : Mandatory adoption of ASBE affected the likelihood of Chinese firms managing earnings toward a positive target.

$\mathrm{H}_{3}$ : Mandatory adoption of ASBE affected the likelihood of Chinese firms recognizing losses in a timely manner.

In this study, similar to a large number of prior examinations of the phenomenon, earnings smoothing $\left(\mathrm{H}_{1}\right)$ is measured in three ways. The first measure is the variability of the change in annual net income $(\Delta N I)$. Each firm's change in net income from the immediately preceding year is regressed on a set of control variables (see equation (1)). The variance of residuals from the regression serves as a proxy for earnings smoothing activities. If firms smooth earnings, relatively small fluctuations in net income from one year to the next are expected to be observed. The control variables are size, growth, equity issuance, debt issuance, leverage, asset turnover, and operating cash flows; all of these factors have been identified in prior research as contributing to earnings volatility. Also firms' listing location, type of shares issued, and industry group are included as control variables.

$$
\begin{gathered}
\Delta N I_{i t}=\alpha_{0}+\alpha_{1} S_{Z I Z E_{i t}}+\alpha_{2} \text { GROWTH }_{i t}+\alpha_{3} \text { EISSUE }_{i t}+\alpha_{4} D I S S U E_{i t}+\alpha_{5} L E V_{i t}+ \\
\alpha_{6} T U R N_{i t}+\alpha_{7} \text { OCF }_{i t}+\alpha_{8} E X C H_{i t}+\alpha_{9} D U A L_{i t}+\alpha_{10} B S H R_{i t}+\alpha_{11-16} I N D_{i t}+\varepsilon_{i t}
\end{gathered}
$$

where:

SIZE $=$ the natural logarithm of year-end total assets;

GROWTH = percentage change in sales;

EISSUE $=$ percentage change in common stock outstanding;

DISSUE $=$ percentage change in total liabilities;

$L E V=$ year-end total liabilities divided by year-end total shareholders' equity;

$T U R N=$ sales divided by year-end total assets;

$O C F=$ net cash flow from operating activities divided by year-end total assets;

$E X C H=$ an indicator variable that equals one if the company is listed on the Shenzhen Stock Exchange, and zero if the listing is on the Shanghai Stock Exchange;

$D U A L=$ an indicator variable that equals one if the company issues two types of shares (A and $\mathrm{B})$, and zero if a firm issues only one type (either A or B);

$B S H R=$ an indicator variable that equals one if only $\mathrm{B}$ shares are issued, and zero otherwise;

$I N D=$ dummy variables for industry fixed effects, based on the CSMAR classifications.

The second measure for income smoothing assessment is the ratio of the variability of the change in net income $(\triangle N I)$ to the variability of the change in operating cash flows $(\triangle O C F)$. The variance of the residuals from the regression of $\triangle O C F$ on the control variables represents the variability of $\triangle O C F$. If firms manage earnings through accruals, the variability of $\triangle N I$ should be lower than that of $\triangle O C F$, a low ratio suggests 
earnings smoothing. Similar to equation (1), the variability of $\triangle O C F$ is obtained from this model:

$$
\begin{gathered}
\triangle O C F_{i t}=\alpha_{0}+\alpha_{1} S_{I Z E_{i t}}+\alpha_{2} \text { GROWTH }_{i t}+\alpha_{3} E_{I S S U E_{i t}}+\alpha_{4} D I S S U E_{i t}+\alpha_{5} L E V_{i t}+ \\
\alpha_{6} T{ } N_{i t}+\alpha_{7} O C F_{i t}+\alpha_{8} E X C H_{i t}+\alpha_{9} D U A L_{i t}+\alpha_{10} B S H R_{i t}+\alpha_{11-16} I N D_{i t}+\varepsilon_{i t}
\end{gathered}
$$

The final measure of earnings management is the Spearman coefficient of partial correlation between the residuals of accruals and the residuals of operating cash flows. Accruals (ACC) are computed as net income minus operating cash flows. A more negative correlation between cash flows and accruals indicates earnings management since firms can use accruals to smooth the variability in earnings. Separate regressions of cash flows (equation (3)) and accruals (equation (4)) are computed on the set of control variables - excluding the cash flow one. The Spearman correlation coefficient is based on the residuals from these two regressions.

$$
\begin{gathered}
\text { OCF }_{i t}=\alpha_{0}+\alpha_{1} \text { SIZE }_{i t}+\alpha_{2} \text { GROWTH }_{i t}+\alpha_{3} \text { EISSUE }_{i t}+\alpha_{4} \text { DISSUE }_{i t}+\alpha_{5} L E V_{i t}+ \\
\alpha_{6} \text { TURN }_{i t}+\alpha_{7} \text { EXCH }_{i t}+\alpha_{8} D U A L_{i t}+\alpha_{9} \text { BSHR }_{i t}+\alpha_{10-15} I N D_{i t}+\varepsilon_{i t} \\
\text { ACC }_{i t}=\alpha_{0}+\alpha_{1} \text { SIZE }_{i t}+\alpha_{2} \text { GROWTH }_{i t}+\alpha_{3} \text { EISSUE }_{i t}+\alpha_{4} D I S S U E_{i t}+\alpha_{5} L E V_{i t}+ \\
\alpha_{6} \text { TURN }_{i t}+\alpha_{7} E \text { XCH }_{i t}+\alpha_{8} \text { DUAL }_{i t}+\alpha_{9} B S H R_{i t}+\alpha_{10-15} I N D_{i t}+\varepsilon_{i t}
\end{gathered}
$$

To assess whether ASBE affects a firm's likelihood of managing income toward a positive target (this addresses $\mathrm{H}_{2}$ ), previous studies are followed in defining $N I$, scaled by total assets, as small positive (SPOS) if it falls within the range of 0 and 0.01 . Thus, SPOS is a dummy variable that takes the value of one if scaled $N I$ lies in the interval 0 and 0.01 and zero otherwise. A logit model is applied to regress SPOS on an indicator variable, POST, which equals one if the observation is in the post-ASBE period and zero otherwise (equation (5)). The usual control variables also are included in this model.

$$
\begin{gathered}
\text { SPOS }_{i t}=\alpha_{0}+\alpha_{1} \text { POST }_{i t}+\alpha_{2} \text { SIZE }_{i t}+\alpha_{3} \text { GROWTH }_{i t}+\alpha_{4} \text { EISSUE }_{i t}+\alpha_{5} \text { DISSUE }_{i t}+\alpha_{6} L E V_{i t}+ \\
\alpha_{7} \text { TURN }_{i t}+\alpha_{8} O C F_{i t}+\alpha_{9} E \text { CH }_{i t}+\alpha_{10} D U A L_{i t}+\alpha_{11} \text { BSHR }_{i t}+\alpha_{12-17 I N D_{i t}}+\varepsilon_{i t}
\end{gathered}
$$

To measure the likelihood, for the third hypothesis, of firms reporting losses in a timely manner, $N I$, scaled by total assets, is defined as large negative (LNEG) if it is smaller than -0.20. LNEG is a dummy variable that takes the value of one if scaled $N I$ is less than -0.20 and zero otherwise. Again, a logit model is employed to regress LNEG on an indicator variable, POST, which equals one if the observation is in the post-ASBE period and zero otherwise (equation (6)). The usual control variables again are included.

$$
\begin{gathered}
L_{N E G_{i t}}=\alpha_{0}+\alpha_{1} \text { POST }_{i t}+\alpha_{2} \text { SIZE }_{i t}+\alpha_{3} \text { GROWTH }_{i t}+\alpha_{4} E_{\text {ISSUE }}+\alpha_{5} D I S S U E_{i t}+\alpha_{6} L E V_{i t}+ \\
\alpha_{7} \text { TURN }_{i t}+\alpha_{8} \text { OCF }_{i t}+\alpha_{9} E X C H_{i t}+\alpha_{10} D U A L_{i t}+\alpha_{11} B_{S H R}+\alpha_{12-17} I N D_{i t}+\varepsilon_{i t}
\end{gathered}
$$

\section{Company Sample and Results}

The sample firms are taken from the CSMAR database. Since 2007 is the year that ASBE became effective, the years from 2004 to 2006 were designated as the pre-ASBE period and 2007 to 2009 as the post-ASBE period. Because the number of companies publicly traded is increasing over the years under study, the coverage of CSMAR grows. To ensure that the same firms before and after the event are compared, companies that were publicly traded in year 2003 are used as the base sample for the purpose of computing changes into 2004. Another requirement to assure that the study sample remains intact is that the firms selected must have all needed financial variables in CSMAR from 2003 to 2009.

As shown in Table 1, on December 31, 2003, CSMAR included 1,334 firms traded on either the Shenzhen Stock Exchange (SZSE) or the Shanghai Stock Exchange (SHSE). In this population grouping, 86 companies issued both A and B shares (these are "dual-listed" firms). Since CSMAR "double counts" this type of firm by including the same set of financials twice, one of the two identical data entries for each of the 86 companies 
was excluded in the analysis. Furthermore, 28 firms (two of which were dual-listed) were found to have some missing data elements that were needed in the models. To make certain that consistent model estimation occurred over the six-year study period, all 28 of these firms were removed from the analysis. The final sample consists of 1,220 companies. There are 3,660 firm-year observations in each of the pre-ASBE and post-ASBE periods.

Table 1

Descriptive Statistics Relating to Sample Firms: Sample Selection

\begin{tabular}{|c|c|c|c|c|c|c|}
\hline & \multicolumn{3}{|c|}{ Pre-ASBE } & \multicolumn{3}{|c|}{ Post-ASBE } \\
\hline & 2004 & 2005 & 2006 & 2007 & 2008 & 2009 \\
\hline Initial number of firms as of $12 / 31 / 2003$ & 1,334 & 1,334 & 1,334 & 1,334 & 1,334 & 1,334 \\
\hline Less: Firms with A \& B dual listing (same data) & -86 & -86 & -86 & -86 & -86 & -86 \\
\hline Less: Firms with missing financial data & -28 & -28 & -28 & -28 & -28 & -28 \\
\hline Final sample: Number of firms & 1,220 & 1,220 & 1,220 & 1,220 & 1,220 & 1,220 \\
\hline Total number of firm-year observations & & 3,660 & & & 3,660 & \\
\hline
\end{tabular}

In this final sample, 84 firms are dual-listed; they account for 6.89 percent of the firms studied. Nearly all of the sample firms, a total of 1,114 (91.31 percent), issue only A shares. The remaining 22 firms (1.80 percent) issue B shares solely. As for the listing location, the Shenzhen Stock Exchange has 472 of the sample companies (38.69 percent) and the Shanghai Stock Exchange has the other 748 (61.31 percent). Table 2 shows the detailed breakdown of share types and listing locations.

Table 2

Descriptive Statistics Relating to Sample Firms: Breakdown of Share Type and Listing Location

\begin{tabular}{llcrr}
\hline & Shenzhen Stock Exchange & Shanghai Stock Exchange & Total & Percentage \\
\hline & & & & \\
A and B shares & 41 & 43 & 84 & $6.89 \%$ \\
B shares only & 12 & 10 & 22 & $1.80 \%$ \\
A shares only & 419 & 95 & 1,114 & $91.31 \%$ \\
Total & 472 & 748 & 1,220 & $100.00 \%$ \\
Percentage & $38.69 \%$ & $61.31 \%$ & $100.00 \%$ & \\
\hline
\end{tabular}

Table 3

Descriptive Statistics Relating to Sample Firms: Breakdown of Sample Companies by Industrial Classification

\begin{tabular}{llcc}
\hline CSMAR classification & CSMAR code & Number of firms & Percentage \\
\hline Finance & 0001 & 14 & $1.15 \%$ \\
Public utility & 0002 & 103 & $8.44 \%$ \\
Properties & 0003 & 70 & $5.74 \%$ \\
Conglomerates & 0004 & 212 & $17.38 \%$ \\
Industrials & 0005 & 715 & $58.61 \%$ \\
Commerce & 0006 & 106 & $8.69 \%$ \\
Total & & 1,220 & $100.00 \%$ \\
\hline
\end{tabular}

Based on CSMAR's definition, a company can be categorized into one of six industry groups: finance, public utility, properties, conglomerates, industrials, and commerce. As shown in Table 3, the industrials group has the largest number of firms (715) and accounts for 58.61 percent of the sample; the finance group, the smallest classification studied, has only 14 companies (1.15 percent). 
Table 4 reports descriptive statistics for the regression model test and control variables.

Table 4

Descriptive Statistics for Variables Used in the Analyses

\begin{tabular}{|c|c|c|c|c|c|c|c|c|}
\hline & \multicolumn{3}{|c|}{ Pre-ASBE $(N=3,660)$} & \multicolumn{5}{|c|}{ Post-ASBE $(N=3,660)$} \\
\hline & Mean & Median & Std. Dev. & Mean & & Median & & Std. Dev. \\
\hline \multicolumn{9}{|c|}{ Test Variables } \\
\hline$\Delta N I$ & 0.0054 & 0.0027 & 0.0994 & 0.0087 & & 0.0050 & *** & 0.1185 \\
\hline$\triangle O C F$ & 0.0096 & 0.0088 & 0.1000 & 0.0075 & \multirow[b]{2}{*}{ **** } & 0.0041 & \multirow[b]{2}{*}{ *** } & 0.1095 \\
\hline$A C C$ & -0.0434 & -0.0334 & 0.1007 & -0.0271 & & -0.0232 & & 0.1159 \\
\hline$O C F$ & 0.0535 & 0.0522 & 0.0808 & 0.0528 & \multirow{3}{*}{$\begin{array}{l}* * * * \\
* \\
*\end{array}$} & 0.0494 & \multirow{3}{*}{$\begin{array}{l}* * * \\
* \\
*\end{array}$} & 0.0904 \\
\hline SPOS & 0.1656 & 0.0000 & 0.3717 & 0.1303 & & 0.0000 & & 0.3367 \\
\hline$L N E G$ & 0.0352 & 0.0000 & 0.1844 & 0.0279 & & 0.0000 & & 0.1646 \\
\hline \multicolumn{9}{|c|}{ Control Variables } \\
\hline SIZE & 21.3037 & 21.2399 & 1.0344 & 21.6285 & *** & 21.5726 & *** & 1.2535 \\
\hline GROWTH & 0.2133 & 0.1518 & 0.5036 & 0.2234 & \multirow[b]{2}{*}{ **** } & 0.1013 & *** & 0.8022 \\
\hline EISSUE & 0.0925 & 0.0000 & 0.2252 & 0.1201 & & 0.0000 & \multirow{2}{*}{ **** } & 0.2886 \\
\hline DISSUE & 0.2047 & 0.1022 & 0.4930 & 0.2510 & **** & 0.0916 & & 0.7675 \\
\hline$L E V$ & 1.3516 & 1.0782 & 1.0465 & 1.4156 & \multirow{2}{*}{$\begin{array}{l}* * * \\
* *\end{array}$} & 1.1068 & \multirow{3}{*}{$*$} & 1.1160 \\
\hline TURN & 0.6620 & 0.5375 & 0.5000 & 0.6876 & & 0.5754 & & 0.5164 \\
\hline EXCH & 0.3869 & 0.0000 & 0.4871 & 0.3869 & & 0.0000 & & 0.4871 \\
\hline$D U A L$ & 0.0689 & 0.0000 & 0.2532 & 0.0689 & & 0.0000 & & 0.2532 \\
\hline BSHR & 0.0180 & 0.0000 & 0.1331 & 0.0180 & & 0.0000 & & 0.1331 \\
\hline
\end{tabular}

Notes. ${ }^{*},{ }^{* *},{ }^{* * *}$ Significantly different between two groups at the $10 \%, 5 \%$, and $1 \%$ levels, respectively (two-tailed tests). $\Delta$ NI is the change in annual net income scaled by year-end total assets; $\triangle O C F$ is the change in operating cash flows scaled by year-end total assets; $A C C$ stands for accruals and is the difference between net income and operating cash flows, scaled by year-end total assets; $O C F$ is the annual net cash flow from operating activities scaled by year-end assets; SPOS is a dummy variable that equals 1 if scaled net income is between 0 and 0.01 , otherwise it takes the value $0 ; L N E G$ is a binomial-indicator test variable with value 1 when scaled NI is less than -0.20 and 0 otherwise; SIZE is the natural logarithm of year-end total assets; GROWTH is the percentage change in sales; EISSUE is the percentage change in common stock; DISSUE is the percentage change in total liabilities; $L E V$ stands for leverage and equals year-end total liabilities divided by total year-end shareholders' equity; TURN stands for total asset turnover and equals sales divided by year-end total assets; $E X C H$ is an indicator variable that equals one if a firm is listed on Shenzhen Stock Exchange and zero if it is traded on the Shanghai Stock Exchange; DUAL is an indicator variable that equals one if a firm issues both $\mathrm{A}$ and $\mathrm{B}$ shares and zero otherwise; BSHR is an indicator variable that equals one if a firm issues only B shares and zero otherwise.

With this very large sample tested, there is an expectation that extreme values will be observed. All continuous variables were winsorized at the one percent and 99 percent levels. The average change of net income in the post-ASBE period is higher than that in the pre-ASBE period. This same pattern persists for the median comparison. Both differences are statistically significant. This provides univariate support for $\mathrm{H}_{1}$ that the variability of net income has changed (in this case, increased) after implementation of ASBE. On the contrary, the change in operating cash flows is lower in the post-ASBE period, although the differences in both means and medians are not statistically significant. Accruals (i.e., the difference between net income and operating cash flows) tend to be more negative in the years before firms adopted ASBE, suggesting that firms had bigger accrual amounts and had more accrual items to record prior to ASBE. 
On average, there are fewer instances of small positive earnings after the implementation of ASBE; the difference between the two periods is significant both in means and medians. This outcome provides univariate support for $\mathrm{H}_{2}$ that the pattern of firms managing earnings toward a positive target has changed after ASBE became effective. Similarly, for reporting large negative income, the number of firm-year observations is smaller in the post-ASBE period, lending univariate support to $\mathrm{H}_{3}$ that the way that companies recognize losses appears to differ between the two test periods.

Regarding the control variables, although the same set of companies was used, in the post-ASBE period the firms tend to be slightly larger in size, issue more equity and debt, and have greater financial leverage and total asset turnover. On the other hand, the operating cash flows (these are used in certain of the regression models as a control variable) are fairly comparable between the two periods.

The comparisons of the earnings quality before and after the implementation of ASBE are presented in Table 5 .

Table 5

Earnings Quality Analysis Outcomes

\begin{tabular}{lcc}
\hline & Pre-ASBE $(N=3,660)$ & Post-ASBE $(N=3,660)$ \\
\cline { 2 - 3 } Variability of $\triangle N I$ & 0.0092 & $0.0136^{* * *}$ \\
Variability of $\triangle N I$ over $\triangle O C F$ & $1.5857^{\# \#}$ & 2.2274 \\
Correlation of $A C C$ and $O C F$ & -0.5938 & -0.6226 \\
Small Positive $N I(S P O S)$ & $0.3039^{+++}$ & $0.3581^{++}$ \\
Large Negative $N I(L N E G)$ & \\
\hline Notes. ${ }^{* * * *}$ Significantly different between two groups at the 1\% level (two-tailed tests); ${ }^{++},{ }^{+++}$Significantly different from zero at \\
the $5 \%$ and $1 \%$ levels, respectively (two-tailed tests); ${ }^{*+}$ Significantly less than two at the 5\% level (one-tailed tests).
\end{tabular}

The first three items measure the earnings smoothing activities $\left(\mathrm{H}_{1}\right)$. As indicated by the test item $\Delta N I$, the variance of the residuals from equation (1) in the pre-ASBE period is 0.0092, significantly lower than 0.0136, the variance in the post-ASBE period. Since a lower variance is indicative of income smoothing, companies appear to engage in fewer earnings smoothing activities in the post-adoption period.

Consistent with the first measure, the ratio of the variance of change in net income to the variance of change in cash flows is lower before the ASBE implementation (1.5857) than it is in the post-ASBE period (2.2274). Furthermore, the ratio of 1.5857 is significantly smaller than 2 . Although no statistical test can determine whether the difference in the ratios is significant or not, in this case the ratio changes from significantly less than 2 to larger than 2 between the periods, suggesting that the difference in earnings variability is not caused merely by the difference in cash flow variability. This finding is in line with the first one above.

The final measure is the correlation between accruals and operating cash flows, which should have a negative sign. The correlation in post-ASBE period is -0.6226 , slightly more negative than that in pre-ASBE period of -0.5938 . Though a more negative correlation indicates earnings management, the difference is not statistically different at even the 10 percent level. This finding suggests that the correlation between accruals and operating cash flows remains fairly consistent before and after the adoption of ASBE.

Next, the focus can turn to the likelihood of firms managing earnings toward a positive target $\left(\mathrm{H}_{2}\right)$. Table 5 reports the coefficient of POST from the logit regression, where POST equals one if the observation is from the post-ASBE period. The positive and highly significant coefficient (0.3039) suggests that it is more likely for firms to report small positive earnings after ASBE was implemented than before. This is in contrast to the 
descriptive statistic reported in Table 4 where SPOS has a smaller average (i.e., fewer incidents of small positive earnings) in the post-ASBE period. Nevertheless, the evidence suggests that the probability of firms reporting small positive income has changed after ASBE became effective.

Lastly, there is a reporting on whether a difference in the timeliness of firms recognizing losses between the two test periods $\left(\mathrm{H}_{3}\right)$ has been found. Similar to the previous test, a logit model to regress POST on LNEG, a dummy variable for large negative net income, and the set of control variables is used. As presented in Table 5 , the coefficient of POST is positive and statistically significant (0.3581). This indicates that firms report negative incomes in a timelier manner after the implementation of ASBE.

\section{Discussion and Conclusion}

The question for examination is whether the 2007 mandatory adoption of the IFRS-based accounting standards in China had an impact on the quality of firms' reporting of earnings. Following previous studies, earnings quality is measured on three aspects: earnings smoothing, earnings being managed toward a positive target, and timeliness of firms recognizing losses. To conduct the comparison, three years before and three years after ASBE implementation were chosen for the test period. A final sample of 1,220 companies was obtained from CSMAR, giving 3,660 firm-year observations in each of the comparison periods.

From this testing, evidence was found for less earnings smoothing in the post-adoption period. Specifically, the variability of change in net income declines in the three years after ASBE became mandatory. This pattern continues to hold even after taking into account the variability of change in operating cash flows. Although the difference in correlation between accruals and operating cash flows turns out to be insignificant, the overall findings point to the fact that net income exhibits a higher variability from one period to the other after the adoption of ASBE; this suggests that less earnings smoothing activity occurred in the post-adoption period. Coincidentally, there is a finding that companies tend to manage their earnings toward a positive target in the post-ASBE period. Firms are more likely to recognize losses in a timely manner after the new accounting standards became effective, indicating an improvement in earnings quality.

As discussed in the background literature review section above, this study significantly expands Lin et al. (2012). It is also related to Liu et al. (2011) who examined the impact of ASBE adoption on Chinese firms in the period of 2005 to 2008 . That research is extended here in two very substantial ways: by including a larger number of firms and testing over a longer period of time. The results here are in line with their findings and provide additional support for the positive impact that IFRS-based standards have concerning firms' financial reporting quality.

Several limitations for this study are readily acknowledged. First, information for some control variables, such as each sample firm's auditor and its percentage of closely-held shares, which normally are included in regression models that seek to shed light on earnings quality has not been considered at all in the instant study. To accommodate this, some data source other than CSMAR would have to be accessed. Second, 2007 is the year that compliance with ASBE became mandatory. Data from that year may be noisy as firms adjusted to the new reporting regime. As time goes by and more annual data become available, additional tests over a longer period must be undertaken to confirm the findings given above. Despite these limitations, this is one of very few studies to examine the impact of mandatory adoption of IFRS-based accounting standards in China, an important developing economy. It adds to the ongoing discussion concerning the costs and benefits of IFRS implementation around the globe. 


\section{References}

Armstrong, C. S., Barth, M. E., Jagolinzer, A. D., \& Riedl, E. J. (2010). Market reaction to the adoption of IFRS in Europe. The Accounting Review, 85, 31-61.

Ball, R., Robin, A., \& Wu, J. S. (2003). Incentives versus standards: Properties of accounting income in four East Asian countries. Journal of Accounting and Economics, 36, 235-270.

Barth, M. E., Landsman, W. R., \& Lang, M. H. (2008). International accounting standards and accounting quality. Journal of Accounting Research, 46, 467-498.

Chen, H., Tang, Q., Jiang, Y., \& Lin, Z. (2010). The role of international financial reporting standards in accounting quality: Evidence from the European Union. Journal of International Financial Management \& Accounting, 21, 220-278.

Chen, S., Sun, Z., \& Wang, Y. (2002). Evidence from China on whether a harmonized accounting standard harmonizes accounting practices. Accounting Horizons, 16, 183-197.

Daske, H., Hail, L., Leuz, C., \& Verdi, R. (2008). Mandatory IFRS reporting around the world: Early evidence on the economic consequences. Journal of Accounting Research, 46, 1085-1142.

Deloitte. (2006). Comparison of IFRS and new Chinese accounting standards. New York: Deloitte.

Ding, Y., \& Su, X. (2008). Implementation of IFRS in a regulated market. Journal of Accounting and Public Policy, 27, 474-479.

Echer, E., \& Healy, P. M. (2000). The role of international accounting standards in transitional economies: A study of the People's Republic of China. Retrieved from http://papers.ssrn.com/paper.taf?abstract_id=233598

Horton, J., \& Serafeim, G. (2010). Market reaction to and valuation of IFRS reconciliation adjustments: First evidence from the UK. Review of Accounting Studies, 15, 725-751.

Hung, M., \& Subramanyam, K. R. (2007). Financial statement effects of adopting international accounting standards: The case of Germany. Review of Accounting Studies, 12, 623-657.

Jeanjean, T., \& Stolowy, H. (2008). Do accounting standards matter? An exploratory analysis of earnings management before and after IFRS adoption. Journal of Accounting and Public Policy, 27, 480-494.

Lin, J., Neiva de Figueiredo, J., \& Stagliano, A. J. (2012). The impact of IFRS adoption on earnings quality of Chinese firms. Journal of Accounting and Finance, 26, 3-11.

Liu, C., Yao, L. J., Hu, N., \& Liu, L. (2011). The impact of IFRS on accounting quality in a regulated market: An empirical study of China. Journal of Accounting, Auditing \& Finance, 26, 659-676.

Paananen, M., \& Lin, H. (2009). The development of accounting quality of IAS and IFRS over time: The case of Germany. Journal of International Accounting Research, 8, 31-55.

Peng, S., \& van der Laan Smith, J. (2010). Chinese GAAP and IFRS: An analysis of the convergence process. Journal of International Accounting, Auditing and Taxation, 19, 16-34.

Zhou, H., Xiong, Y., \& Ganguli, G. (2009). Does the adoption of international financial reporting standards restrain earnings management? Evidence from an emerging market. Academy of Accounting and Financial Studies Journal, 13, 43-56. 